Archive for

Organic Chemistry

Arkivoc 2019, part vi, 350-367

\title{
Synthesis of 2-pyridyl oxazoline esters and their organocatalytic application to the enantioselective silane reduction of ketones
}

\author{
Zhenyu Cao, Nadine McCleary, and Patrick O'Leary*
}

National University of Ireland, Galway, School of Chemistry, SMACंT (Synthetic Methods: Asymmetric Catalytic Transformations)

Email: patrick.oleary@nuigalway.ie

Received 10-29-2019

Accepted 12-16-2019

Published on line $01-15-2020$

\section{Abstract}

The synthesis of a number of novel chiral 2-pyridyl oxazoline esters is reported along with the use of these in the enantioselective organocatalytic reduction of ketones. The chiral alcohols were prepared in good to excellent yields (up to 99\%) and were found to catalyse the reduction reactions with good conversions (up to 99\%) and in moderate to good enantioselectivies (up to $65 \%$ at high conversion and $70 \%$ with lower reactivity). The results give an insight into the effects of the catalyst structure on the selectivity observed in the reaction.
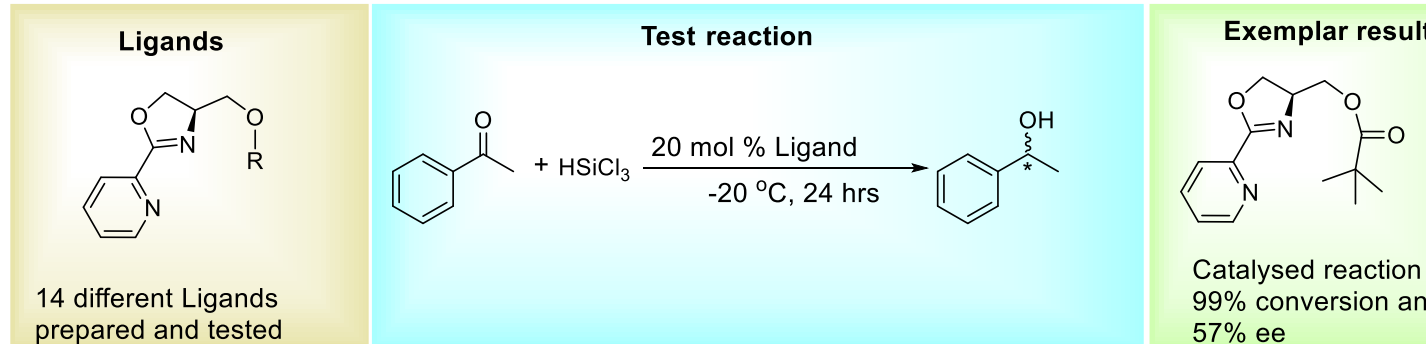

Catalysed reaction to $99 \%$ conversion and $57 \%$ ee

Keywords: Organic synthesis, ligand design, enantioselective, reduction, organocatalytic, oxazoline 


\section{Introduction}

Asymmetric reductions of carbonyl and heterocarbonyl functional groups are fundamental organic transformations. Non stereoselective reduction of ketones and imines can easily be achieved with hydrides but the asymmetric reduction is a very active area of research ${ }^{1}$ with new methods being reported regularly using a wide variety of reactions and reagents for example chiral ligand metal complexes in hydrogenation ${ }^{2,3}$ and transfer hydrogenation, ${ }^{4,5}$ enzymatic reduction ${ }^{6}$ and chiral ligand metal complexes in hydrosilylation. ${ }^{7,8}$

Recently, the asymmetric hydrosilylation of ketones and imines using chiral Lewis base activated trichlorosilane emerged as an effective system capable of competing with the conventional metal-catalysed protocols. ${ }^{9}$ In 1999 and 2001 a major breakthrough in this area was reported by Matsumura in which encouraging enantioselectivities were achieved in the reduction of ketones (up to $51 \%$ ee) and imines (up to $66 \%$ ee). ${ }^{10,11}$ Since then, rapid development in this field has been seen with efficient catalysts reported to catalyse the reaction, including chiral formamides, ${ }^{12-14}$ picolinamides ${ }^{15-17}$ and sulfinamides. ${ }^{18}$

In 2006, Malkov reported the design and synthesis of a series of catalysts based on the pyridyl oxazoline core (Figure 1). ${ }^{19}$ These catalysts afforded good enantioselectivities in the hydrosilylation of both ketones (some in the $80-90 \%$ ee range) and imines (Some $>80 \%$ ee), whereas other catalysts were more often designed to target only one of the reactions.
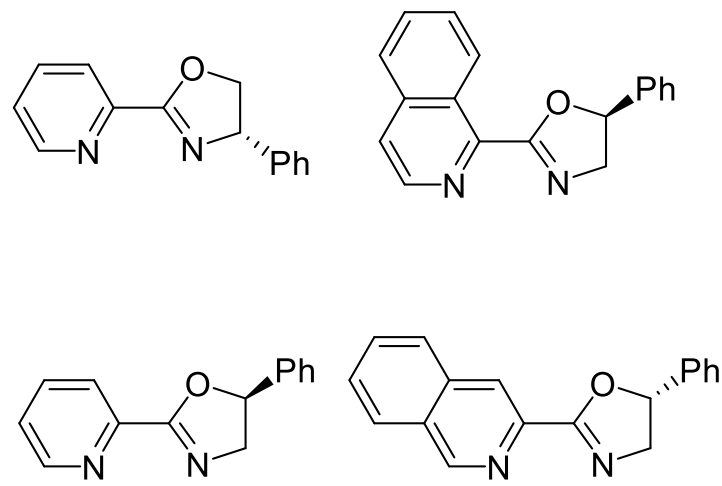

Figure 1. Some pyridyl oxazoline ligands described previously. ${ }^{19}$

\section{Results and Discussion}

Our group has an ongoing interest in the design and application of novel oxazoline based catalytic systems. ${ }^{20-22}$ The initial aim of this project was to synthesize the pyridine substituted oxazoline 1 . After that, a variety of functionalisation reactions would be carried out on the alcohol to give us various ligands with which we could study the effect of variations of functionality in the ligands 2-4 (Figure 2) on their catalytic performance, as organocatalysts in asymmetric catalytic reduction reactions. The ultimate aim of this project is to maximize the catalytic performance of the pyridine-substituted oxazoline ligands and to study the structure-selectivity relationship for this catalyst type in these reductions. 


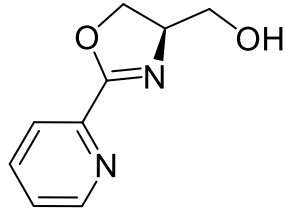

1

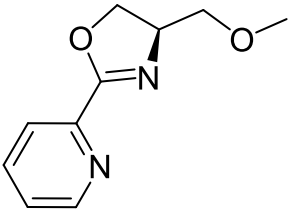

2

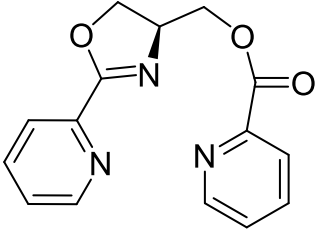

3

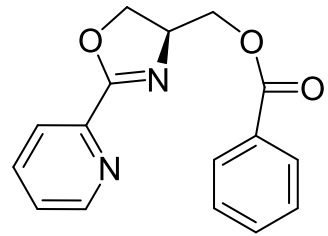

4

Figure 2. Initial target compounds of this work.

We designed a synthetic pathway to the pyridinyl-oxazoline ligand using aspects of the synthesis of similar compounds described by of Balavoine. ${ }^{23}$ However we aimed to start from L-serine 5 , which was much cheaper than the diol which would have been the starting material were we to follow the planned method. Thus, we needed to use an extra synthetic step to reduce the oxazoline ester 6 to the alcohol 1.

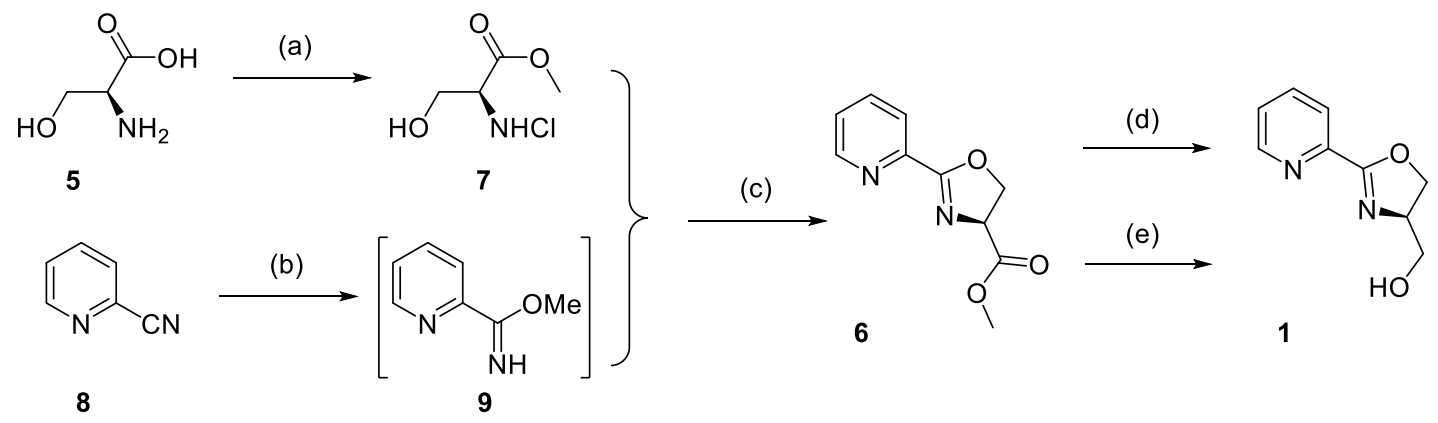

Reagents and conditions: (a) thionyl chloride, $\mathrm{MeOH}, 0{ }^{\circ} \mathrm{C}-\mathrm{rt}$, then reflux overnight, $99 \%$ (b) $\mathrm{Na}$ metal, $\mathrm{MeOH}$, rt, $24 \mathrm{~h} \mathrm{(c)} \mathrm{CH}_{2} \mathrm{Cl}_{2}$, reflux, $2.5 \mathrm{~h}, 78 \%$ (d) $\mathrm{LiAlH}_{4}, \mathrm{Et}_{2} \mathrm{O}, 0{ }^{\circ} \mathrm{C}$-rt, $4 \mathrm{~h}, 31 \%$ (e) $\mathrm{NaBH}_{4}, \mathrm{MeOH}, 0{ }^{\circ} \mathrm{C}$-rt, $4 \mathrm{~h}, 72 \%$ after crystallization.

Scheme 1. Synthesis of pyridinyl-oxazoline ligand 1.

As shown in Scheme 1, the first step involved the protection of L-serine $\mathbf{5}$ as its methyl ester $\mathbf{7}$. Sodium methoxide $(0.4 \mathrm{eq})$ was generated in situ and reacted with the 2-cyano-pyridine 8 at room temperature. The reaction was stirred until full disappearance of the starting material. The carboximidate $\mathbf{9}$ was used directly in the next reaction in which it reacted with the methyl ester 7 to form the key intermediate, the oxazoline ester $\mathbf{6}$, in $78 \%$ yield. Multigram quantities of $\mathbf{6}$ were easily available by this route.

Reduction of the ester group on 6 was attempted with a lithium aluminium hydride protocol ${ }^{25}$. Lithium aluminium hydride (1.2 eq) was reacted with the ester 6 (1-2 g) in ice-cold diethyl ether. After 4 hours the starting material had been consumed. The reaction was quenched by the Fieser work-up method and the crude product was purified by column chromatography on silica gel. Isolation of the oxazoline alcohol 1 was achieved in a disappointing 31\% yield. Other work-up methods were also attempted to quench the reaction, but no significant improvement was achieved. Due to the modest yield an alternative reduction method using sodium borohydride/methanol ${ }^{26}$ was later attempted. Sodium borohydride (2.0 eq) was reacted with the ester 6 in methanol. After the work-up, the product was purified by crystallization $\left(\mathrm{CH}_{2} \mathrm{Cl}_{2} / \mathrm{EtOAc}\right)$ to give the alcohol 1 as a white powder in a much more satisfactory $72 \%$ yield. This reduction method became the method of choice for our study. 

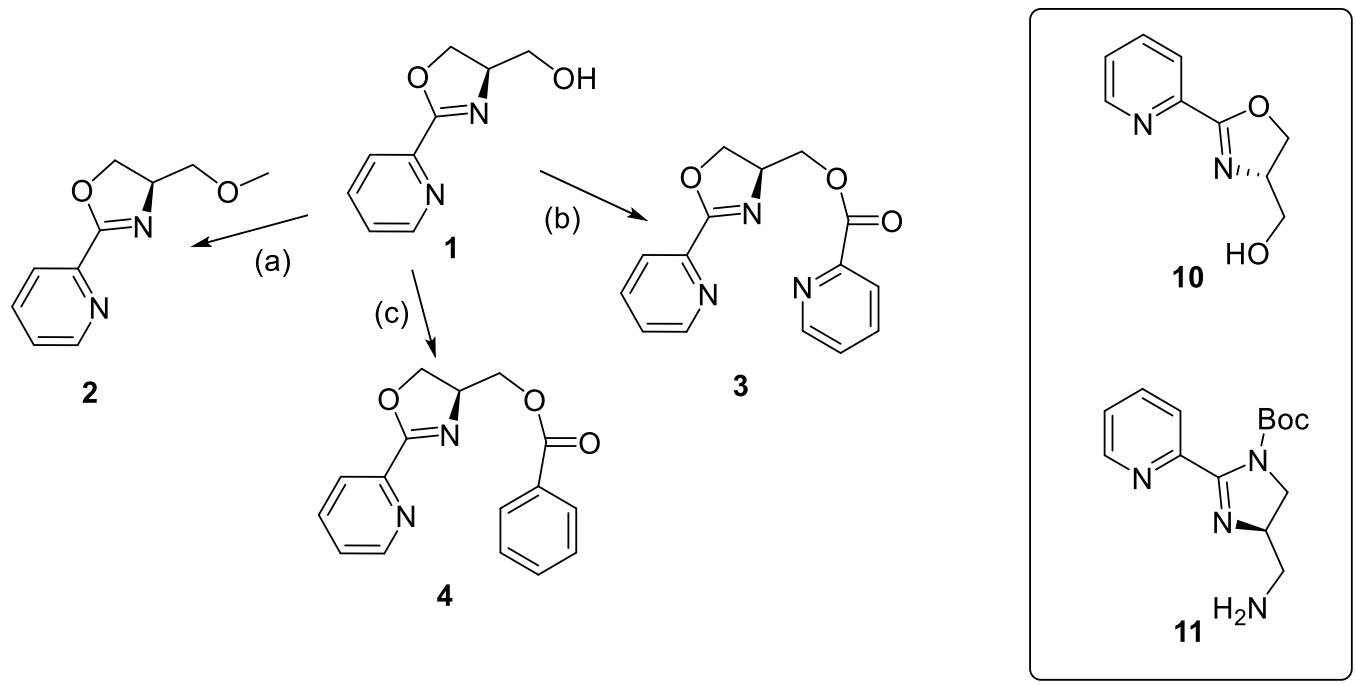

Reagents and conditions: (a) $\mathrm{NaH}, \mathrm{Mel}, 0{ }^{\circ} \mathrm{C}$ to r.t, $3 \mathrm{~h}, 76 \%$ (b) 2-picolinic acid, 4-DMAP, dicyclohexylcarbodiimide (DCC), $\mathrm{CH}_{2} \mathrm{Cl}_{2}, 0^{\circ} \mathrm{C}$ to r.t, $4 \mathrm{~h}, 53 \%$ (c) benzoyl chloride, $\mathrm{Et}_{3} \mathrm{~N}, \mathrm{CH}_{2} \mathrm{Cl}_{2}, 0{ }^{\circ} \mathrm{C}$ to r.t, $3 \mathrm{~h}$, $88 \%$

Scheme 2. Synthesis of ligands 2-4, related known compounds $\mathbf{1 0}$ and $\mathbf{1 1 .}$

With the oxazoline 1 in hand, three variations of the sidearm were developed (Scheme 2). These modifications aimed to investigate the effect of varying the group attached to the chiral center particularly to see what, if any, changes would induce increased interactions between the ligand and the catalytic centre. The increased interactions may give catalytic systems with better selectivity. Ligand $\mathbf{2}$ with ether functionality and ligand $\mathbf{3}$ with a pyridine ester were expected to demonstrate different coordination chemistry in the reaction both to each other and the original ligand $\mathbf{1}$. The benzoate ester $\mathbf{4}$, a similar compound to 3, was also synthesized to help establish the coordination effects and catalytic outcomes attributable to the pyridine nitrogen on 4. The ligands 2-4 prepared from 1 are all novel compounds and their synthesis was by conventional synthetic methods as outlined in Scheme 2.

During the course of this study we became aware of a report by Christoffers ${ }^{27}$ where oxazoline 10 was synthesised (Scheme 2) via a different, more complex, route involving TBS protection and deprotection of the alcohol. This was the opposite enantiomer of oxazoline 1. This compound was a synthetic intermediate in the synthesis of ligand 11, and has not been used as a ligand in any catalytic reactions.

In a preliminary report by Kočovský et al on the use of 2-pyridyl mono(oxazoline) ligands a mechanism was proposed for the hydrosilylation of aromatic ketones. In this report the team proposed $N, N$-chelation of trichlorosilane to the mono(oxazoline) ligand. ${ }^{19}$ Consequently, their mechanistic proposal involves coordination of both the oxazoline nitrogen and the pyridyl nitrogen to the trichlorosilane.

We wanted to investigate this hypothesis. Therefore, we completed the synthesis of a 4-pyridyl mono(oxazoline) ligand in which the pyridyl moiety is derived from 4-cyanopyridine as opposed to 2cyanopyridine. Our reasoning behind the use of 4-substituted pyridine ring was to maintain similar electronic properties between each family of ligands to allow us to directly study the coordinating effect of the nitrogen on the 2-position of the pyridine moiety.

We used the same synthetic methodology as previously described to construct the ligand, with the substitution of 4-cyanopyridine. Primary alcohol 12 can be derived from the cyclisation of methyl-(L)-serine 7 
with 4-cyanopyridine, followed by reduction of the resulting methyl ester $\mathbf{1 3}$ to the primary alcohol. Finally, esterification with the acid chloride led to the isolation of the ligand $\mathbf{1 4}$ (Scheme 3).

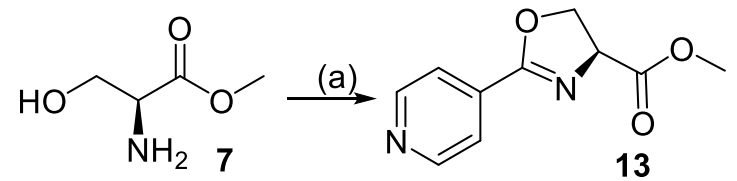

(b)<smiles>Cc1ccc(C(=O)OCC2COC(c3ccncc3)=N2)cc1</smiles>

Reagents and conditions: (a) (i) 4-cyanopyridine, $\mathrm{Na}$ metal, $\mathrm{MeOH}, \mathrm{rt}, 40 \mathrm{~h}$ then 7, $\mathrm{CH}_{2} \mathrm{Cl}_{2}, 2.5 \mathrm{~h}, \mathrm{reflux}, 61 \%$ (over 2 steps) (b) $\mathrm{NaBH}_{4}, \mathrm{MeOH}, 4 \mathrm{~h}, 0{ }^{\circ} \mathrm{C}-\mathrm{rt}, 77 \%$ (c) acid chloride, $\mathrm{Et}_{3} \mathrm{~N}, 18 \mathrm{~h}, 0^{\circ} \mathrm{C}-\mathrm{rt}, 68 \%$

Scheme 3. Synthesis of 4-pyridyl ligand 14.

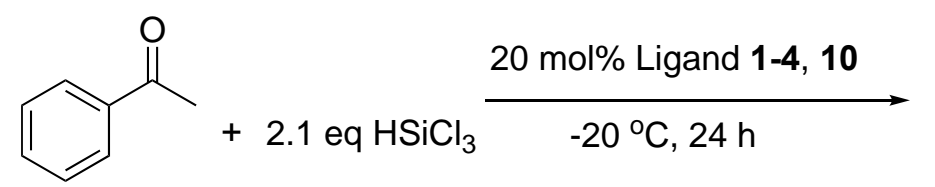

15<smiles>[CH2+]C(=Nc1ccccc1)c1ccccc1</smiles>

17<smiles>CC(O)c1ccccc1</smiles>

16<smiles>CC(Nc1ccccc1)c1ccccc1</smiles>

18

Scheme 4. Trichlorosilane-assisted hydrosilylations.

The hydrosilylation reactions of both ketone 15 and imine 17 were performed following identical procedures with the obvious exception of the use of different starting materials. The procedure described below was used for the hydrosilylation of acetophenone 15. As shown in Scheme 4, trichlorosilane (2.1 equivalents) was added to a solution of acetophenone 15 (1.0 equivalent) and $20 \mathrm{~mol} \%$ of the appropriate ligand $1-4$ at $-20{ }^{\circ} \mathrm{C}$ in dichloromethane $(2 \mathrm{~mL})$. The reaction was stirred for 24 hours during which time 1phenylethanol 16 was formed. The crude product was purified by column chromatography and the enantiomeric excess (ee) measured using GC using a chiral CYCLODEX- $\beta$ column.

The hydrosilylation of an imine was carried out in a similar manner. $N$-(1-phenylethylidene)aniline 17 was used instead of acetophenone 15 , and the reaction was performed at $0{ }^{\circ} \mathrm{C}$ instead of $-20{ }^{\circ} \mathrm{C}$. The crude product 18 was purified by column chromatography and the ee of the purified product was measured using chiral HPLC.

The catalytic results obtained in these two reactions using ligands 1-4 and ligand 14 are recorded in Tables 1 and 2 . 
Table 1. Hydrosilylation of acetophenone

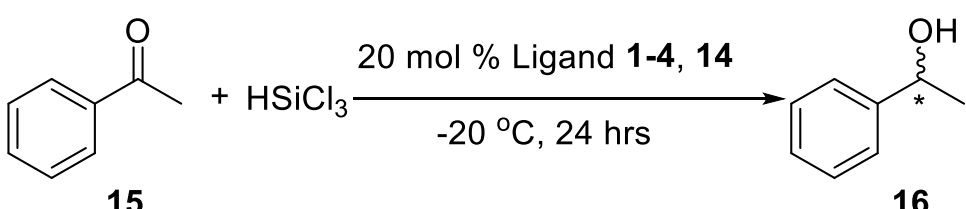

15

16

\begin{tabular}{lll}
\hline Ligand & Conversion (\%) & ee (\%) $(R)$ \\
\hline Alcohol 1 & 99 & 42 \\
Methyl ether 2 & 91 & 41 \\
Picolinate ester 3 & 20 & 28 \\
Benzoate 4 & 99 & 62 \\
4-pyridyl ligand 14 & 0 & - \\
\hline
\end{tabular}

As shown in Table 1 for the hydrosilylation of acetophenone, the original alcohol ligand $\mathbf{1}$ showed outstanding activity, giving 99\% conversion to the desired product. The modified ligands were also highly efficient in catalysing the reaction with the exception of ligand $\mathbf{3}$ where a significant drop in activity was observed.

The enantiomeric excesses obtained with these ligands ranged from $28-62 \%$. The transformation of the hydroxyl side-arm into its methyl ether counterpart (1 to $\mathbf{2}$ ) did not appear to make a difference to the enantioselectivity achieved in the reduction. The highest ee (62\%) was achieved using ligand 4, and interestingly, the lowest one (28\%) was produced by the related ligand $\mathbf{3}$ where the phenyl ring on the sidearm was replaced by a pyridine. The ees achieved in the ketone reduction while not as high as those reported by Malkov ${ }^{19}$ are encouraging in terms of designing future generations of these ligands to achieve high selectivity.

In the hydrosilylation using ligand $\mathbf{3}$, it was observed that some precipitate was gradually formed during the addition of trichlorosilane. It was speculated that the hypervalent silicate compound generated from the silane and ligand 3 precipitated due to its reduced solubility at low temperature $\left(-20^{\circ} \mathrm{C}\right)$. If that was the case, the reaction was catalysed by the reduced amount of homogeneous catalyst or if the precipitated silicate complex was also a catalyst, the catalysis was performed with both homogeneous and heterogeneous catalysts. We believe that these changes in the behaviour of the complexes were part of the reason for the poor catalytic performance of $\mathbf{3}$.

The complete lack of reactivity observed when ligand 14 the 4-pyridyl ligand was used seems to add credence to the mechanism proposed by Kočovský. It is apparent that moving the pyridyl nitrogen effectively kills the catalysis so the 2-pyridyl group is key. 
Table 2. Hydrosilylation of of $\mathrm{N}$-(1-phenylethylidene)aniline<smiles>CC(Nc1ccccc1)c1ccccc1</smiles>

\begin{tabular}{lll}
\hline Ligand & Conversion $(\%)$ & ee $(\%)$ \\
\hline Alcohol 1 & 99 & $28(R)$ \\
& $99\left(-10^{\circ} \mathrm{C}\right)$ & $33(R)$ \\
Methyl ether 2 & 99 & $10(S)$ \\
Picolinate ester 3 & 99 & $14(R)$ \\
Benzoate 4 & 99 & $4(R)$ \\
\hline
\end{tabular}

In the hydrosilylation of $\mathrm{N}$-(1-phenylethylidene)aniline, the activities of the ligands were excellent, with 99\% conversions obtained in all cases (Table 2 ). The enantioselectivities achieved in this reaction were not as good as in the hydrosilylation of acetophenone. The highest ee (28\%) was obtained with the alcohol ligand 1 favouring the $(R)$ enantiomer. Interestingly, changing the side-arm from the $\mathrm{OH}$ group to an OMe group resulted in a significant change of selectivity. Reaction using ligand $\mathbf{2}$ gave product with a 10\% ee favouring the $(S)$ enantiomer, a 38\% swing in ee compared to that obtained with ligand 1 . Thereby we postulate that the $\mathrm{OH}$ sidearm of ligand $\mathbf{1}$ is playing a role mechanistically. As this was not seen in the hydrosilylation of acetophenone, it is likely that the proton of the $\mathrm{OH}$ side-arm was interacting, probably via hydrogen-bonding, with the imine substrate. Replacing the $\mathrm{OH}$ group of $\mathbf{1}$ with the OMe group would prevent this interaction and this would account for the significant change of selectivity observed.

Having determined how synthetically simple the preparation of benzoate ester $\mathbf{4}$ had turned out to be and having seen that we could achieve enantioselective catalysis in the reduction reactions, we decided to prepare another six related derivatives. Using different acyl chlorides but the same method we prepared 1924 in yields ranging from $75-87 \%$ (Figure 3).

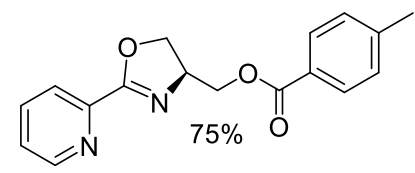

19

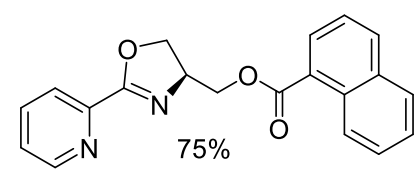

21<smiles>COc1ccc(C(=O)OCC2COC(c3ccccn3)=N2)cc1</smiles>

23<smiles>O=C(OCC1COC(c2ccccn2)=N1)c1ccc(Cl)cc1</smiles>

20<smiles>O=C(OCC1COC(c2ccccn2)=N1)c1ccc([N+](=O)[O-])cc1</smiles>

22<smiles>O=C(OC[C@@H]1COC(c2ccccn2)=N1)C12CC3CC(CC(C3)C1)C2</smiles>

24

Figure 3. Second group of 2-pyridyl ligands prepared for this study. 
Table 3. Hydrosilylation of acetophenone

\begin{tabular}{llll}
\hline Entry & Ligand & Conversion (\%) & ee (\%) $)^{\text {a }}$ \\
\hline 1 & 19 & 78 & 44 \\
2 & 20 & 3 & 48 \\
3 & 21 & $>99$ & 1 \\
4 & 22 & $>99$ & 46 \\
5 & 23 & 65 & 0.6 \\
6 & 24 & 99 & 47 \\
\hline
\end{tabular}

${ }^{a}$ determined by chiral GC (Cyclodex $\beta$ column, $120^{\circ} \mathrm{C}, 20 \mathrm{~min}$ )

The hydrosilylation reaction was used to test the catalytic performance of the chiral mono(oxazoline) ligands 19-24. The results for the reaction shown in Scheme 5, using 20 mol\% of appropriate ligand are shown in Table 3.

Excellent conversions were observed for ligands 21, 22 and $\mathbf{2 4}$. Modest enantioselectivities were obtained for ligands 19, 20, 22, 24. The ligands with the napthyl ester $\mathbf{2 1}$ and the $p$-methoxyphenyl ester $\mathbf{2 3}$ show the poorest enantioselectivities overall, such that almost no facial selectivity is shown (Entries 3 and 5). It appears that alkyl, electron-deficient aryl or mildly electron-rich aryl groups are tolerated well but the electron-rich methoxy-aryl is less reactive and less selective and the napthoate is not well tolerated when it comes to selectivity. Benzoate esters appear superior to ethers in terms of selectivity.

To rationalise the results Kočovský and co-workers obtained, they postulated the following mechanistic transformation (Scheme 5)
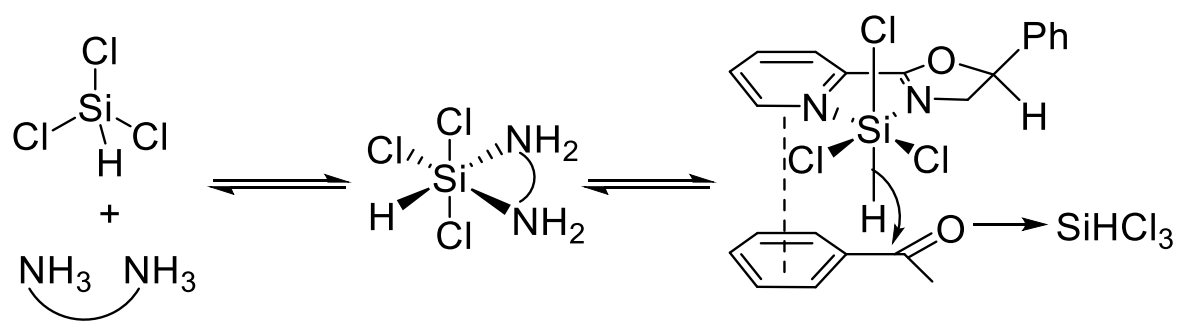

Scheme 5. Kočovský’s proposed mechanism for the hydrosilylation using 2-pyridyl oxazoline ligands.

$\mathrm{N}, \mathrm{N}$-Chelation of $\mathrm{Cl}_{3} \mathrm{SiH}$ of by the 2-pyridyl mono(oxazoline) leads to the formation of the activated hydrosilylating species, seen in Scheme 5 above. Trichlorosilane does not reduce the carbonyl species without the presence of a Lewis base, supporting the formation of the hexacoordinated species seen above. Another molecule of $\mathrm{Cl}_{3} \mathrm{SiH}$ is likely to activate the ketone by coordination to the oxygen atom. It is unlikely that the carbonyl will displace a chloride ion to coordinate to the activated silicon centre, as the corresponding four membered transition state would not be energetically favourable. This ketone- $\mathrm{Cl}_{3} \mathrm{SiH}$ complex can then approach the catalyst- $\mathrm{Cl}_{3} \mathrm{SiH}$ from the less hindered face, as dictated by the orientation of the chiral centre. Kočovský et al. also suggested that this interaction will also be stabilised by arene-arene interactions between the phenyl ring of the substrate and the pyridyl ring of the chiral catalyst (Scheme 5). 
We postulate that a possible competitive arene-arene interaction between the incoming acetophenone and the napthyl moiety may be playing a role in the lack of selectivity seen for ligand $\mathbf{2 1 .}$

As established above, $p$-methoxyphenyl ester substituted ligand $\mathbf{2 3}$ was the second ligand to show disappointing selectivity. This effect could be attributed to the strong electron-donating effect exhibited by the para-methoxy moiety. Through resonance, it is possible to move the lone pair of electrons, originating from the oxygen of the methoxy group, as far as the ester oxygen. This may suggest that where the ligand is an ester this ester is somehow involved in the reaction mechanism and altering the electron density on the oxygen affects the selectivity.

Following on from this we wanted to establish the versatility of the reaction as regards to substrate scope. Chiral alcohols are important building blocks in organic synthesis and are commonly used synthons in the pharmaceutical industry, such as in the total synthesis of Duloxetine. ${ }^{28}$ Therefore, it is desirable that our ligands are able to catalyse the transformation of various ketones. Scheme 6 shows the transformation of 1-(4methyl)ethanone $\mathbf{2 5}$ to the corresponding alcohol 26.

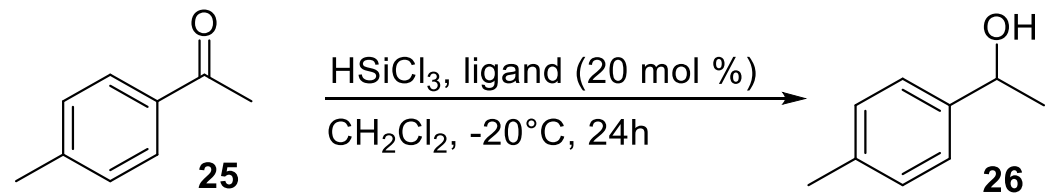

Scheme 6. Hydrosilylation of 1-(4-methyl)ethanone 25.

The transformation was carried out as described for acetophenone $\mathbf{1 5}$ above. The percentage conversion was calculated by comparing the amount of unreacted 1-(4-methyl)ethanone 25 [signal at 2.54 ppm $(3 \mathrm{H})$ ] to that of the product 26 [signal at $1.48 \mathrm{ppm}(3 \mathrm{H})$ ] in the ${ }^{1} \mathrm{H}-\mathrm{NMR}$ spectrum. Following purification, the ee was measured by chiral GC. The results of the reactions using each ligand are shown in Table 4 below.

Table 4. Hydrosilylation of 1-(4-methyl)ethanone

\begin{tabular}{llll}
\hline Entry & Ligand & Conversion $(\%)$ & ee $(\%)^{\mathrm{a}}$ \\
\hline 1 & 19 & $>99$ & 38 \\
2 & 20 & 3 & 38 \\
3 & 21 & 92 & 10.5 \\
4 & 23 & 91 & 3 \\
5 & 24 & 7 & 35 \\
\hline
\end{tabular}

${ }^{a}$ determined by chiral GC (Cyclodex $\beta$ column, $120^{\circ} \mathrm{C}, 20 \mathrm{~min}$ )

The same general trend can be seen to be as was seen for acetophenone (Table 3). Low selectivities were again observed for ligands $\mathbf{2 1}$ and $\mathbf{2 3}$ and again the remaining ligands showed almost consistent selectivities. Although an overall decrease in enantioselectivity was seen for ligands 19, 20 and 24 (Entries 1, 2 and 5) compared to their performance with acetophenone. We can conclude that the addition of the methyl group has an overall negative effect on the selectivity of the reaction. 
To that point we had seen that ligands with an ester side-arm showed good selectivity in the reduction of acetophenone. Our initial benzoate gave the highest ee with variations in the aromatic group leading to decreased selectivity and no clear correlation in performance with electronic effects in the aromatic group. The larger naphthyl ester showed no selectivity. We noted that the adamantyl ester performed quite well and we prepared a number of other non-aromatic esters 27-30 to assess whether these would give better performance and a clearer correlation between performance and the ester group. Moving away from aromatic esters also allowed us to try chiral esters to see if there was an additive effect from multiple chiral centres in the ligand. We also prepared the pyridin-2-ylmethyl ether $\mathbf{3 0}$ to see what effect a third coordinating nitrogen might have on the selectivity. Thus, using similar chemistry to before, we prepared ligands 27-29 (Figure 4)

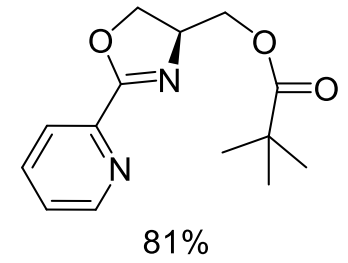

27

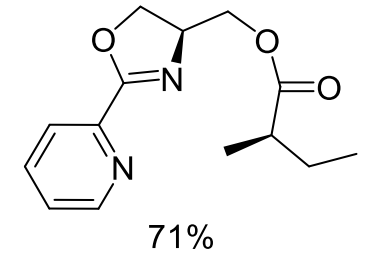

28

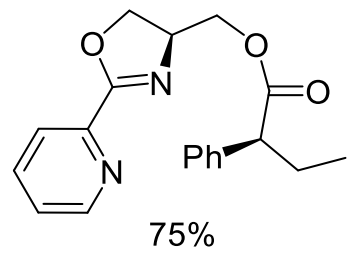

29<smiles>O=S(=O)(O)c1ccccn1</smiles>

30

Figure 4. Third group of pyridin-2-yl ligands prepared for this study.

Table 5. Catalytic results in the hydrosilylation of acetophenone using ligands 27-30

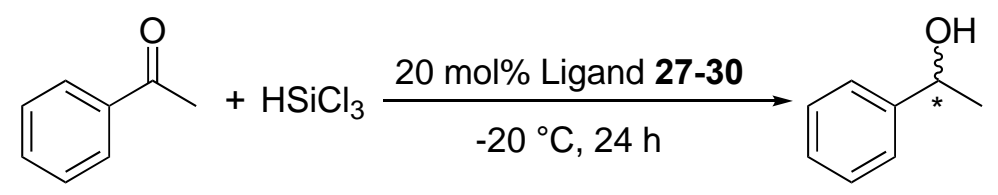

15
16

\begin{tabular}{ll} 
Conversion (\%) & ee (\%) \\
\hline &
\end{tabular}


These proved to be equally active to those studied previously, giving conversions to the chiral product ranging from $85-99 \%$. The ee obtained with the pyridin-2-ylmethyl ether 30 (40\%) was similar to that obtained with the alcohol ligand $\mathbf{1}$ (42\%). This result added to our suspicion that the carbonyl group of the ligand ester was a key feature required to achieve high enantioselectivity using this type of ligand. The similar ees achieved in the reaction by ligands $\mathbf{1}$ and $\mathbf{3 0}$ also indicated that the coordination of the side-arm pyridin-2-yl nitrogen to the silicon centre was less likely.

Interestingly, varying the steric bulk of the group attached to the carbonyl group did not appear to have substantial influence on enantioselectivity. In fact, ligands bearing different ester side-arms achieved similar enantioselectivities in the reactions. The pivalate ester $\mathbf{2 7}$ delivered the highest ee (57\%) among the four modified ligands. The benzoate ester 29 exhibited similar enantioselectivity (52\%) to the ligand bearing a chiral group on the ester $\mathbf{2 8}$ (55\%). It had been hoped that this chiral ester group would show a substantial additive (or reductive) effect on the stereoselectivity.

As they gave very promising selectivities, ligands $\mathbf{4}$ and $\mathbf{2 7}$, were selected to study the effect of reaction temperature on the reactivity and selectivity.

Table 6. Catalytic results of $\mathbf{4}$ and $\mathbf{2 7}$ with variation in reaction temperature

\begin{tabular}{lllll} 
Ligands & Temp $\left({ }^{\circ} \mathrm{C}\right)$ & Time (h) & Conversion(\%) & ee (\%) \\
\hline & -20 & 24 & 99 & $62(\mathrm{R})$ \\
& -40 & 24 & 99 & $53(\mathrm{R})$ \\
\hline
\end{tabular}

As shown in Table 6 , ligand 4 was highly active even at $-40{ }^{\circ} \mathrm{C}$, although its enantioselectivity was slightly reduced at that temperature. Similar precipitation was observed during the addition of trichlorosilane, as was described above for the reaction catalysed by ligand $\mathbf{3}$. It was once again speculated that the hypervalent silicon complex was precipitated due to reduced solubility, which contributed to the decline of selectivity in the reaction because this reduced the effective concentration of the catalyst, which could lead to this selectivity decrease.

Ligand 27 also demonstrated impressive activities in this reaction. When the reaction was running at $40{ }^{\circ} \mathrm{C}$ a slight drop in conversion (3\%) was observed compared to the reaction at $-20{ }^{\circ} \mathrm{C}$. At $-78{ }^{\circ} \mathrm{C}$ this ligand was still reasonably active as 14\% conversion was achieved in 6 hours. During the tests with ligand 27, improvements in selectivity were seen as the temperature was reduced. The ees ranged from from $57 \%$ at -20 ${ }^{\circ} \mathrm{C}$ to $65 \%$ at $-40{ }^{\circ} \mathrm{C}$ and finally $70 \%$ at $-78{ }^{\circ} \mathrm{C}$.

\section{Conclusions}

We have reported the synthesis of four novel ligands and their application in asymmetric reduction reactions. The ligands acted as organocatalysts demonstrating consistently high activities in the hydrosilylation of a 
ketone and an imine. The exception was ligand 3, which produced only a $20 \%$ conversion in the hydrosilylation of a ketone ketone, possibly due to the solubility issue as was discussed previously.

The ees obtained in the hydrosilylation of acetophenone were improved by the modifications. The ees obtained in this reaction increased from $41 \%$ using the original alcohol 1 to $62 \%$ using ligand 4 and in general, ligands with ester side-arms were more selective. With the $t$-Bu substituted ligand which showed good selectivity and activity in the reaction at $-20{ }^{\circ} \mathrm{C}$, reduction at $-40{ }^{\circ} \mathrm{C}$ still gave good conversion and an ee of $65 \%$. At $-78^{\circ} \mathrm{C}$ we achieved an ee of $70 \%$ albeit with a decrease in catalyst activity.

The ees obtained in the reduction of $\mathrm{N}$-(1-phenylethylidene)aniline were adversely affected by the modifications to the side-arm as the highest ee (28\%) was produced by the alcohol 1.

We are continuing to develop these ligands with modifications based on these results and the application these ligands to other reactions as organocatalysts and as part of catalytic complexes.

\section{Experimental Section}

General. All procedures were carried out under an atmosphere of nitrogen unless otherwise stated. All solvents were distilled prior to use as follows: dichloromethane and acetonitrile were distilled from calcium hydride, toluene and tetrahydrofuran were distilled from sodium benzophenone ketyl or dried through an Innovative Technology Pure Solv PS-MD-5 Purification System. Organic phases were dried using anhydrous magnesium sulphate or sodium sulphate. All chemicals were purchased from Aldrich Chemical Company, Fisher Scientific or Acros Organics and were used without further purification. All asymmetric reactions were carried out using standard Schlenk line techniques and all Schlenk tubes were heat dried under vacuum to remove moisture prior to use.

Melting points were measured on a Stuart Scientific SMP3 or SMP11 apparatus and are uncorrected. IR spectra were measured on a Perkin Elmer Spectrum One FT-IR, in which liquid samples were measured as thin films and solids were measured directly. Optical rotations were measured on a Uniplol L1000 polarimeter at $589 \mathrm{~nm}(\mathrm{Na})$ in a $1 \mathrm{dm}$ cell; concentrations $(c)$ are expressed in $\mathrm{g} / 100 \mathrm{~mL}$. [ $\alpha]_{\mathrm{D}}$ is the specific optical rotation of a compound and is measured in units of deg. $\mathrm{mL} \cdot \mathrm{g}^{-1} \cdot \mathrm{dm}^{-1}$. Thin layer chromatography (TLC) was carried out on pre-coated silica gel plates (Merck 60 F254); column chromatography was carried out using Apollo Scientific silica gel 40-63 micron. Visualisation was achieved by UV (254 nm) light detection, vanillin stain or ninhydrin stain. High resolution mass spectra were carried out using electrospray ionisation (ESI) on a Walters LCT Premier XE spectrometer by manual peak matching. ${ }^{1} \mathrm{H}$ NMR $(400 \mathrm{MHz})$ and ${ }^{13} \mathrm{C} N M R(100 \mathrm{MHz})$ spectra were recorded on a JEOL ECX-400 NMR spectrometer. All spectra were recorded at probe temperatures $\left(\sim 20{ }^{\circ} \mathrm{C}\right)$ in deuterated chloroform $\left(\mathrm{CDCl}_{3}\right)$ unless otherwise stated, using tetramethylsilane (TMS) as an internal standard. Chemical shifts are expressed in parts per million (ppm) and coupling constants in Hertz ( $\mathrm{Hz})$, unless indicated all coupling constants represent 3 bond couplings.

All chiral HPLC analysis was carried out on a Varian Prostar instrument, with a UV/Vis detector at the specified wavelength, with a CHIRACEL OD $0.46 \mathrm{~cm} \Phi \times 25 \mathrm{~cm}$ column under conditions described for each experiment. All chiral GC analysis was carried out on a Varian 3900 instrument, using helium as the mobile phase and a FID (Flame lonisation Detector), with a CYCLODEX- $\beta 0.25 \mathrm{~mm} \Phi \times 30 \mathrm{~m}$ column under conditions described for each experiment.

Methyl L-serinate hydrochloride (7). Thionyl chloride $(4.4 \mathrm{~mL}, 60 \mathrm{mmol})$ was added dropwise to a suspension of L-serine 5 (6.34 g, $60 \mathrm{mmol})$ in anhydrous $\mathrm{MeOH}(60 \mathrm{~mL})$ at $0{ }^{\circ} \mathrm{C}$. The mixture was allowed to warm to $\mathrm{rt}$ and 
stirred for a further $2 \mathrm{~h}$ at $\mathrm{rt}$. The reaction was then heated at reflux overnight. The solvent was removed under reduced pressure and the resulting solid residue was stirred in $\mathrm{Et}_{2} \mathrm{O}$ until a fine powder precipitated. The powder was removed by filtration and the supernatant dried under vacuum to yield compound 7 (9.33 $\mathrm{g}$, $59.9 \mathrm{mmol}, 99 \%)$ as a white powder.

${ }^{1} \mathrm{H}$ NMR spectroscopic data was in accordance with the literature. ${ }^{24,29}$

${ }^{1} \mathrm{H}$ NMR $\left(\mathrm{D}_{2} \mathrm{O}, 400 \mathrm{MHz}\right): \delta(\mathrm{ppm}) 4.29(1 \mathrm{H}, \mathrm{t}, J 3.8), 4.08(2 \mathrm{H}, \mathrm{m}, J 12.5,3.8), 3.87(3 \mathrm{H}, \mathrm{s}) ;{ }^{13} \mathrm{C} \mathrm{NMR}\left(\mathrm{D}_{2} \mathrm{O}, 100\right.$ $\mathrm{MHz}): \delta$ (ppm) 169.0, 59.3, 54.7, 53.7.

Methyl (4S)-2-(pyridin-2-yl)-4,5-dihydrooxazole-4-carboxylate (6). Sodium metal (560 mg, $24 \mathrm{mmol}$ ) was added to anhydrous $\mathrm{MeOH}(60 \mathrm{~mL})$ and the mixture was stirred until bubbling ceased at which stage 2cyanopyridine 8 ( $6.24 \mathrm{~g}, 60 \mathrm{mmol}$ ) was added. After stirring for $24 \mathrm{~h}$, the solvent was removed under reduced pressure and the crude product 9 was transferred to a suspension of compound 7 (9.33 g, $59.9 \mathrm{mmol})$ in anhydrous $\mathrm{CH}_{2} \mathrm{Cl}_{2}(60 \mathrm{~mL})$. The reaction mixture was then heated at reflux for $2.5 \mathrm{~h}$, cooled and the inorganic precipitate filtered off. The solvent was removed under reduced pressure and the resulting crude product was purified by column chromatography (silica gel, EtOAc-PE, 80:20) to yield the oxazoline ester 6 (9.66 g, 46.8 mmol, 78\%) as a yellow oil. $[\alpha]_{\mathrm{D}}{ }^{20}+96.8$ (c 0.50, $\left.\mathrm{CHCl}_{3}\right) ;{ }^{1} \mathrm{H} \mathrm{NMR}\left(\mathrm{CDCl}_{3}, 400 \mathrm{MHz}\right): \delta$ (ppm) $8.46(1 \mathrm{H}, \mathrm{d}, J 4.7$ $\mathrm{Hz}), 7.85(1 \mathrm{H}, \mathrm{d}, J 7.9 \mathrm{~Hz}), 7.56(1 \mathrm{H}, \mathrm{td}, J 7.8,1.2 \mathrm{~Hz}), 7.23-7.15(1 \mathrm{H}, \mathrm{m}), 4.80(1 \mathrm{H}, \mathrm{dd}, J 10.8,8.2 \mathrm{~Hz}), 4.55-$ $4.42(2 \mathrm{H}, \mathrm{m}), 3.57(3 \mathrm{H}, \mathrm{s}) ;{ }^{13} \mathrm{C} \mathrm{NMR}\left(\mathrm{CDCl}_{3}, 101 \mathrm{MHz}\right): \delta(\mathrm{ppm}) 171.1,165.2,149.7,145.8,136.7,126.0,124.3$, 70.1, 68.6, 52.6; IR $\left(\mathrm{cm}^{-1}\right)$ : 2954, 1737, 1636, 1581, 1570, 1436, 1364, 1204.

[(4R)-2-(Pyridin-2-yl)-4,5-dihydrooxazol-4-yl]methanol (1). Sodium borohydride pellets (1.52g, $40 \mathrm{mmol})$ were added to an ice-cold solution of compound 6 (4.12 g, $20 \mathrm{mmol})$ in $\mathrm{MeOH}(200 \mathrm{~mL})$. After gas evolution had ceased, the reaction was allowed to warm up to $\mathrm{rt}$ and was further stirred for $4 \mathrm{~h}$. The solvent was removed and the solid residue was partitioned between $\mathrm{H}_{2} \mathrm{O}(50 \mathrm{~mL})$ and $\mathrm{CH}_{2} \mathrm{Cl}_{2}(50 \mathrm{~mL})$, the layers were separated and the aqueous layer was extracted with $\mathrm{CH}_{2} \mathrm{Cl}_{2}(50 \mathrm{~mL} \times 3)$. The combined organic layers were dried $\left(\mathrm{Na}_{2} \mathrm{SO}_{4}\right)$ and filtered, and the solvent removed under reduced pressure. The crude product was then purified by crystallization $\left(\mathrm{CH}_{2} \mathrm{Cl}_{2} /\right.$ EtOAc) to yield the oxazoline alcohol $1(2.55 \mathrm{~g}, 14.3 \mathrm{mmol}, 72 \%)$ as a white powder.

All spectroscopic data was in accordance with the literature. ${ }^{27}$

${ }^{1} \mathrm{H} \mathrm{NMR}\left(\mathrm{CDCl}_{3}, 400 \mathrm{MHz}\right): \delta(\mathrm{ppm}) 8.69(1 \mathrm{H}, \mathrm{ddd}, J$ 4.8, 1.6, $0.9 \mathrm{~Hz}), 7.93(1 \mathrm{H}, \mathrm{dt}, J$ 7.9, $1.2 \mathrm{~Hz}), 7.76(1 \mathrm{H}, \mathrm{td}, J$ 7.8, 1.6 Hz), $7.35(1 \mathrm{H}, \mathrm{ddd}, J$ 7.6, 4.8, $0.9 \mathrm{~Hz}), 4.58(1 \mathrm{H}, \mathrm{dd}, J$ 9.7, $7.3 \mathrm{~Hz}), 4.57-4.45(1 \mathrm{H}, \mathrm{m}), 4.41(1 \mathrm{H}, \mathrm{t}, J 7.4$ $\mathrm{Hz}), 3.98(1 \mathrm{H}, \mathrm{dd}, J 11.4,3.1 \mathrm{~Hz}), 3.70(1 \mathrm{H}, \mathrm{dd}, J 11.0,3.4 \mathrm{~Hz}), 2.45(1 \mathrm{H}, \mathrm{s}) ;{ }^{13} \mathrm{C} \mathrm{NMR}\left(\mathrm{CDCl}_{3}, 101 \mathrm{MHz}\right): \delta(\mathrm{ppm})$ $164.5,150.0,146.3,136.8,125.8,124.0,70.0,68.5,64.2$.

(4R)-2-(Pyridin-2-yl)-4,5-dihydrooxazol-4-ylmethyl pyridine-2-carboxylate (3). Dicyclohexylcarbodiimide (680 $\mathrm{mg}, 3.3 \mathrm{mmol}$ ) was added portionwise to an ice-cold solution of oxazoline alcohol 1 (534 $\mathrm{mg}, 3 \mathrm{mmol}$ ), picolinic acid (406 mg, $3.3 \mathrm{mmol}$ ) and 4-dimethylaminopyridine $(36.5 \mathrm{mg}, 0.3 \mathrm{mmol})$ in anhydrous $\mathrm{CH}_{2} \mathrm{Cl}_{2}(20$ $\mathrm{mL}$ ). After stirring for $10 \mathrm{~min}$, the reaction was allowed to warm up to rt and stirred for a further $4 \mathrm{~h}$. The mixture was filtered and concentrated under reduced pressure. The resulting crude product was then purified by column chromatography (silica gel, $\mathrm{CH}_{2} \mathrm{Cl}_{2}-\mathrm{MeCN}, 95: 5$ ) to yield picolinate ester 3 (453 $\mathrm{mg}, 1.6 \mathrm{mmol}, 53 \%$ ) as a colorless oil. $[\alpha]_{\mathrm{D}}{ }^{20}+70.5$ (c $\left.0.49, \mathrm{CHCl}_{3}\right) ;{ }^{1} \mathrm{H} \mathrm{NMR}\left(\mathrm{CDCl}_{3}\right): \delta 8.78-8.72(2 \mathrm{H}, \mathrm{m}), 8.14-8.05(2 \mathrm{H}, \mathrm{m}), 7.87-$ $7.76(2 \mathrm{H}, \mathrm{m}), 7.52-7.39(2 \mathrm{H}, \mathrm{m}), 4.79-4.90(1 \mathrm{H}, \mathrm{m}), 4.74-4.64(2 \mathrm{H}, \mathrm{m}), 4.57(1 \mathrm{H}, \mathrm{dd}, \mathrm{J} 11.2,6.5 \mathrm{~Hz}), 4.50(1 \mathrm{H}$, dd, J 8.8, 7.6 Hz); ${ }^{13} \mathrm{C} \mathrm{NMR}\left(\mathrm{CDCl}_{3}\right): \delta 164.8,164.5,149.9,149.8,147.5,146.2,137.0,136.7,127.0,125.8$, 125.3, 124.2, 70.8, 66.9, 65.6; IR $\left(\mathrm{cm}^{-1}\right)$ : 3422, 2964, 1732, 1640, 1583, 1133; ESI-HRMS calcd for $\mathrm{C}_{15} \mathrm{H}_{13} \mathrm{~N}_{3} \mathrm{O}_{3}$ 284.1035 $\left[\mathrm{M}+\mathrm{H}^{+}\right]$, found $m / z$ 284.1034.

(4R)-2-(Pyridin-2-yl)-4,5-dihydrooxazol-4-ylmethyl benzoate (4). Benzoyl chloride (510 mg, $3.6 \mathrm{mmol}$ ) was added slowly to an ice-cold solution of oxazoline alcohol 1 (534 mg, $3 \mathrm{mmol}$ ) and $\mathrm{Et}_{3} \mathrm{~N}(450 \mathrm{mg}, 4.5 \mathrm{mmol}$ ) in 
anhydrous $\mathrm{CH}_{2} \mathrm{Cl}_{2}(20 \mathrm{~mL})$. The reaction was allowed to warm up to rt and stirred for a further $3 \mathrm{~h}$ before it was quenched by $\mathrm{H}_{2} \mathrm{O}(2 \mathrm{~mL})$. The resulting mixture was washed with $\mathrm{H}_{2} \mathrm{O}(2 \times 15 \mathrm{~mL})$, dried $\left(\mathrm{Na}_{2} \mathrm{SO}_{4}\right)$ and concentrated under reduced pressure to give the crude product, which was then purified by column chromatography (silica gel, EtOAc-PE, 90:10) to yield benzoate ester 4 (744 mg, $2.64 \mathrm{mmol}, 88 \%$ ) as a light yellow oil. $[\alpha]_{D}{ }^{20}+16.7\left(\mathrm{c} 0.28, \mathrm{CHCl}_{3}\right) ;{ }^{1} \mathrm{H} \mathrm{NMR}\left(\mathrm{CDCl}_{3}\right): \delta 8.72(1 \mathrm{H}, \mathrm{dd}, J 4.8,1.7 \mathrm{~Hz}), 8.06(1 \mathrm{H}, \mathrm{d}, J 8.0 \mathrm{~Hz}$,$) ,$ $7.99(2 \mathrm{H}, \mathrm{dd}, J$ 8.1, $1.1 \mathrm{~Hz}), 7.79(1 \mathrm{H}, \mathrm{td}, J 7.8,1.8 \mathrm{~Hz}), 7.57-7.48(1 \mathrm{H}, \mathrm{m}), 7.45-7.34(3 \mathrm{H}, \mathrm{m}), 4.83-4.71(1 \mathrm{H}$, $\mathrm{m}), 4.66(1 \mathrm{H}, \mathrm{dd}, J 9.8,8.6 \mathrm{~Hz}), 4.59(1 \mathrm{H}, \mathrm{dd}, J 11.3,4.3 \mathrm{~Hz}), 4.53-4.44(2 \mathrm{H}, \mathrm{m}) ;{ }^{13} \mathrm{C} \mathrm{NMR}\left(\mathrm{CDCl}_{3}\right): \delta 166.4$, $164.5,149.8,146.3,136.7,133.1,129.7,128.5,126.0,124.2,70.6,66.1,65.8 ; \mathrm{IR}\left(\mathrm{cm}^{-1}\right): 2969,1717,1640$, 1582, 1110; ESI-HRMS calcd for $\mathrm{C}_{16} \mathrm{H}_{14} \mathrm{~N}_{2} \mathrm{O}_{3} \mathrm{Na} 305.0902\left[\mathrm{M}+\mathrm{Na}^{+}\right]$, found $\mathrm{m} / z 305.0904$.

2-[(4R)-4-Methoxymethyl-4,5-dihydrooxazol-2-yl]pyridine (2). Sodium hydride (60\% dispersion in mineral oil, $192 \mathrm{mg}, 4.8 \mathrm{mmol}$ ) was added to an ice-cold solution of oxazoline alcohol 1 (534 mg, $3 \mathrm{mmol}$ ) in anhydrous THF $(20 \mathrm{~mL})$. After the bubbling caused by gas evolution ceased, Mel $(511 \mathrm{mg}, 3.6 \mathrm{mmol}$ ) was added slowly and the reaction was allowed to warm up to $\mathrm{rt}$. After stirring the mixture for a further $3 \mathrm{~h}$, the precipitate was filtered off and the filtrate was concentrated under reduced pressure. The resulting residue was partitioned between $\mathrm{H}_{2} \mathrm{O}(15 \mathrm{~mL})$ and $\mathrm{CH}_{2} \mathrm{Cl}_{2}(15 \mathrm{~mL})$, and the separated aqueous layer was further extracted with $\mathrm{CH}_{2} \mathrm{Cl}_{2}$ $(2 \times 15 \mathrm{~mL})$. The combined organic layers were dried $\left(\mathrm{Na}_{2} \mathrm{SO}_{4}\right)$, filtered and concentrated under reduced pressure to give the crude product, which was then purified by column chromatography (silica gel, EtOAc$\mathrm{MeOH}, 95: 5)$ to yield the methyl ether $2(437 \mathrm{mg}, 2.28 \mathrm{mmol}, 76 \%)$ as a light-yellow oil. [ $\alpha]^{\mathrm{D}}{ }_{20}+40.0$ (c 1.00 , $\left.\mathrm{CHCl}_{3}\right) ;{ }^{1} \mathrm{H}$ NMR $\left(\mathrm{CDCl}_{3}\right): \delta 8.69(1 \mathrm{H}, \mathrm{ddd}, J 4.6,1.6,0.9 \mathrm{~Hz}), 8.04(1 \mathrm{H}, \mathrm{d}, J 7.8 \mathrm{~Hz}), 7.76(1 \mathrm{H}, \mathrm{td}, J 7.8,1.8 \mathrm{~Hz})$, $7.43-7.34(1 \mathrm{H}, \mathrm{m}), 4.62-4.48(2 \mathrm{H}, \mathrm{m}), 4.41-4.33(1 \mathrm{H}, \mathrm{m}),, 3.73-3.64(1 \mathrm{H}, \mathrm{m}), 3.54-3.45(1 \mathrm{H}, \mathrm{m}), 3.39(3 \mathrm{H}$, s); ${ }^{13} \mathrm{C} \mathrm{NMR}\left(\mathrm{CDCl}_{3}\right): \delta$ 164.0, 149.8, 146.6, 136.7, 125.7, 124.1, 74.6, 71.2, 66.6, 59.4; IR $\left(\mathrm{cm}^{-1}\right): 3412,2901$, 1641, 1583, 1113; ESI-HRMS calcd for $\mathrm{C}_{10} \mathrm{H}_{12} \mathrm{~N}_{2} \mathrm{O}_{2} 193.0977\left[\mathrm{M}+\mathrm{H}^{+}\right]$, found $\mathrm{m} / z$ 193.0975.

\section{Asymmetric trichlorosilane-assisted hydrosilylation of aromatic ketone and imine. General procedure $B$}

All Schlenk tubes and round-bottom flasks were flame dried under vacuum and re-filled with nitrogen gas before being used in these reactions. Aromatic ketone or imine (1.0 equiv) was added to a solution of ligand (20 mol \%) in anhydrous $\mathrm{CH}_{2} \mathrm{Cl}_{2}(2 \mathrm{~mL})$ at the appropriate temperature. Trichlorosilane (2.1 equiv) was then added and the reaction mixture was stirred at that temperature for a specific period of time.

The reaction was quenched by aqueous $\mathrm{NaHCO}_{3}(2 \mathrm{~mL})$ and the resulting mixture was extracted with $\mathrm{CH}_{2} \mathrm{Cl}_{2}(2$ $x 5 \mathrm{~mL}$ ). The combined organic layers were dried $\left(\mathrm{NaSO}_{4}\right)$ and concentrated under reduced pressure to give the crude product. $\mathrm{A}^{1} \mathrm{H}$ NMR spectrum of the crude product was recorded to determine the percentage conversion of this reaction. [For the reduction of acetophenone, the $\mathrm{CH}_{3}$ signal of the unreacted ketone appeared at $2.58 \mathrm{ppm}(3 \mathrm{H})$ versus the $\mathrm{CH}_{3}$ signal of the product, appearing at $1.52 \mathrm{ppm}(3 \mathrm{H})$; for the reduction of $\mathrm{N}$-(1-phenylethylidene)aniline, the $\mathrm{CH}_{3}$ signal of the unreacted imine appeared at $2.26 \mathrm{ppm}(3 \mathrm{H})$ versus the $\mathrm{CH}_{3}$ signal of the product, at $\left.1.43 \mathrm{ppm}(3 \mathrm{H})\right]$. The crude product was then purified by column chromatography (silica gel). The enantiomeric excess (ee) of the purified product was measured using chiral GC (Cyclodex- $\beta 30$ $\mathrm{m} \times 0.252 \mathrm{~mm} 0.25 \mu \mathrm{m}$ ) or chiral HPLC (DAICEL Chiracel OD $25 \mathrm{~cm} \times 4.6 \mathrm{~mm} 5 \mu \mathrm{m}$ ).

Methyl-(4S)-2-(pyridin-4-yl)-4,5-dihydrooxazole-4-carboxylate (13). To a stirring solution of anhydrous $\mathrm{MeOH}$ $(80 \mathrm{~mL})$ at $\mathrm{rt}$ was added $\mathrm{Na}$ metal $(760 \mathrm{mg}, 32 \mathrm{mmol})$ under $\mathrm{N}_{2}$. Upon cessation of gas evolution, 4cyanopyridine $(8.48 \mathrm{~g}, 0.08 \mathrm{~mol}$ ) was added and the resulting mixture was stirred at $\mathrm{rt}$ for $40 \mathrm{~h}$. Concentration at reduced pressure yielded an off-white solid, which was dissolved in $\mathrm{CH}_{2} \mathrm{Cl}_{2}(60 \mathrm{~mL})$. Following this, ester 7 $(7.05 \mathrm{~g}, 0.06 \mathrm{mmol})$ was added and the resulting mixture was heated to reflux and stirred for $2.5 \mathrm{~h}$. The solution was allowed to cool to $\mathrm{rt}$ and excess solvent was removed under vacuum. The resulting oil was dissolved in EtOAc/ $\mathrm{H}_{2} \mathrm{O}(30 \mathrm{~mL} / 30 \mathrm{~mL})$ and the separated aqueous layer was extracted with $\mathrm{EtOAc}(3 \times 30 \mathrm{~mL})$. The combined organic extracts were dried over $\mathrm{NaSO}_{4}$, filtered and concentrated to yield $\mathbf{1 3}$ as brown oil. 
Purification of crude 13 was achieved by column chromatography in EtOAc:MeOH (95:5) to yield 13 as a clear oil (7.61 g, 61\%). $[\alpha]_{\mathrm{D}}+103.2\left(c 5.05 \times 10^{-3}, \mathrm{CHCl}_{3}, 20^{\circ} \mathrm{C}\right),{ }^{1} \mathrm{H} \mathrm{NMR}\left(400 \mathrm{MHz}, \mathrm{CDCl}_{3}\right) \delta 8.69(2 \mathrm{H}, \mathrm{d}, J 5.9 \mathrm{~Hz}), 7.78$ $(2 \mathrm{H}, \mathrm{d}, J 5.9 \mathrm{~Hz}), 4.96(1 \mathrm{H}, \mathrm{dd}, J 10.7,8.2 \mathrm{~Hz}), 4.71(1 \mathrm{H}, \mathrm{m}), 4.61(1 \mathrm{H}, \mathrm{m}), 3.80(3 \mathrm{H}, \mathrm{s}) \mathrm{ppm} ;{ }^{13} \mathrm{C} \mathrm{NMR}(100 \mathrm{MHz}$, $\left.\mathrm{CDCl}_{3}\right) \delta 171.1,164.7,150.3,134.2,122.1,69.9,68.7,53.0$ ppm; IR 2983, 2887, 1741, $1530 \mathrm{~cm}^{-1}$; ESI-HRMS calcd. for $\mathrm{C}_{10} \mathrm{O}_{3} \mathrm{~N}_{2} \mathrm{H}_{10} 207.0769(\mathrm{M}+\mathrm{H})^{+}$found $\mathrm{m} / z 207.0748$.

[(4R)-2-(Pyridin-4-yl)-4,5-dihydrooxazol-4-yl]methanol (12). To a stirring solution of 13 (4.86 g, $23.34 \mathrm{mmol})$ at $0{ }^{\circ} \mathrm{C}$ in $\mathrm{MeOH}(360 \mathrm{~mL})$ was added $\mathrm{NaBH}_{4}(3.20 \mathrm{~g}, 83.6 \mathrm{mmol})$. Upon cessation of gas evolution the resulting solution was heated to $\mathrm{rt}$ and stirred under $\mathrm{N}_{2}$ for $4 \mathrm{~h}$. Excess $\mathrm{MeOH}$ was removed under vacuum, and the resulting yellow solid was dissolved in $\mathrm{CH}_{2} \mathrm{Cl}_{2} / \mathrm{H}_{2} \mathrm{O}(15 \mathrm{~mL} / 15 \mathrm{~mL})$. The aqueous layer was extracted with $\mathrm{CH}_{2} \mathrm{Cl}_{2}$ $(5 \times 15 \mathrm{~mL})$. The combined organic extracts were dried over $\mathrm{NaSO}_{4}$, filtered and concentrated under reduced pressure to yield crude 12 as an off-white solid. Recrystallisation of the crude product from $\mathrm{CH}_{2} \mathrm{Cl}_{2} / \mathrm{EtOAc}$ at 0 ${ }^{\circ} \mathrm{C}$ yielded 12 as a white solid (3.23g, 77\%). [ $\left.\alpha\right]_{\mathrm{D}}+63.1$ (c $\left.5.10 \times 10^{-3}, \mathrm{CHCl}_{3}, 20{ }^{\circ} \mathrm{C}\right) ;{ }^{1} \mathrm{H} \mathrm{NMR}\left(400 \mathrm{MHz}, \mathrm{CDCl}_{3}\right)$ $\delta 8.62(2 \mathrm{H}, \mathrm{d}, J 4.5 \mathrm{~Hz}), 7.64(2 \mathrm{H}, \mathrm{d}, J 4.5 \mathrm{~Hz}), 4.54-4.38(3 \mathrm{H}, \mathrm{m}), 4.00(1 \mathrm{H}, \mathrm{d}, J 11.6 \mathrm{~Hz}), 3.68(1 \mathrm{H}, \mathrm{d}, J 11.7 \mathrm{~Hz})$ ppm; ${ }^{13} \mathrm{C} \mathrm{NMR}\left(400 \mathrm{MHz}, \mathrm{CDCl}_{3}\right) \delta 163.8,150.2(2 \times \mathrm{CH}), 134.5,122.0(2 \times \mathrm{CH}), 69.6,68.4,63.5 ; \mathrm{IR} 3293,2903$, $1604,845 \mathrm{~cm}^{-1}$; MP 49-51 ${ }^{\circ} \mathrm{C}$; ESI-HRMS calcd. for $\mathrm{C}_{9} \mathrm{O}_{2} \mathrm{~N}_{2} \mathrm{H}_{10} 179.0820(\mathrm{M}+\mathrm{H})^{+}$found $\mathrm{m} / z 179.0812$.

[(4S)-2-(Pyridin-4-yl)-4,5-dihydrooxazol-4-yl]methyl-4-methybenzoate (14). To a stirring solution of 12 (216 $\mathrm{mg}, 1.2 \mathrm{mmol})$ in $\mathrm{CH}_{2} \mathrm{Cl}_{2}(5 \mathrm{~mL})$ at $0{ }^{\circ} \mathrm{C}$ was added $\mathrm{NEt}_{3}(0.33 \mathrm{~mL}, 2.4 \mathrm{mmol})$ and $p$-toluoyl chloride $(0.24 \mathrm{~mL}, 1.8$ $\mathrm{mmol}$ ). The reaction was stirred at $0{ }^{\circ} \mathrm{C}$ after which it was heated to rt and stirred for $18 \mathrm{~h}$. Addition of $\mathrm{H}_{2} \mathrm{O}(5$ $\mathrm{mL}$ ) was followed by extraction of the aqueous layer with $\mathrm{CH}_{2} \mathrm{Cl}_{2}(3 \times 5 \mathrm{~mL})$. The combined organic extracts were washed with brine $(10 \mathrm{~mL})$, dried over $\mathrm{NaSO}_{4}$, filtered and concentrated in vacuo. The resulting oil was purified by column chromatography (PE:EtOAc, 9:1) to yield the mono(oxazoline) ligand 14 as a white solid (233 mg, 68\%). $[\alpha]_{D}+18.0$ (c $\left.5.00 \times 10^{-3}, \mathrm{CHCl}_{3}, 20{ }^{\circ} \mathrm{C}\right) ;{ }^{1} \mathrm{H} \mathrm{NMR}\left(400 \mathrm{MHz}, \mathrm{CDCl}_{3}\right) \delta 8.72(2 \mathrm{H}, \mathrm{d}, J 6.0 \mathrm{~Hz}), 7.85$ $(2 \mathrm{H}, \mathrm{d}, J 8.2 \mathrm{~Hz}), 7.79(2 \mathrm{H}, \mathrm{d}, J 6.0), 7.18(2 \mathrm{H}, \mathrm{d}, J 8.2 \mathrm{~Hz}), 4.74-4.70(1 \mathrm{H}, \mathrm{m}), 4.60-4.52(2 \mathrm{H}, \mathrm{m}), 4.46-4.40(2 \mathrm{H}$, m), $2.38(3 \mathrm{H}, \mathrm{s}) \mathrm{ppm} ;{ }^{13} \mathrm{C} \mathrm{NMR}\left(100 \mathrm{MHz}_{\mathrm{CDCl}}\right) \delta 166.5,163.6,150.3(2 \times \mathrm{CH}), 143.9,134.7,129.7(2 \times \mathrm{ArCH})$, $129.2(2 \times \mathrm{ArCH}), 126.9,122.0(2 \times \mathrm{CH}), 70.4,65.9,65.9,21.8 \mathrm{ppm} ; \mathrm{IR} 2959,2898,1715,1648,837 \mathrm{~cm}^{-1} ; \mathrm{mp}$ 105-108 ${ }^{\circ} \mathrm{C}$; ESI-HRMS calcd. for $\mathrm{C}_{17} \mathrm{O}_{3} \mathrm{~N}_{2} \mathrm{H}_{16} 297.1239$ found $(\mathrm{M}+\mathrm{H})^{+} \mathrm{m} / z$ 297.1225.

[(4S)-2-(Pyridin-2-yl)-4,5-dihydrooxazol-4-yl]methylnaphthalene-1-carboxylate (21). This was prepared according to the procedure reported above for benzoate 3 using oxazoline 1 (288 $\mathrm{mg}, 1.6 \mathrm{mmol})$ in $\mathrm{CH}_{2} \mathrm{Cl}_{2}(5$ $\mathrm{mL}), \mathrm{NEt}_{3}(0.45 \mathrm{~mL}, 3.2 \mathrm{mmol})$ and 1-napthoyl chloride $(0.37 \mathrm{~mL}, 2.4 \mathrm{mmol})$. The resulting crude product was purified by column chromatography (PE:EtOAc, 9:1) to yield the mono(oxazoline) ligand 21 as a viscous strawcoloured oil (489 mg, 75\%). [ $\alpha]_{\mathrm{D}}+5.1$ (c $\left.5.10 \times 10^{-3}, \mathrm{CHCl}_{3}, 20{ }^{\circ} \mathrm{C}\right) ;{ }^{1} \mathrm{H}-\mathrm{NMR}\left(400 \mathrm{MHz}, \mathrm{CDCl}_{3}\right) \delta 8.90-8.85(1 \mathrm{H}$, $\mathrm{m}), 8.73(1 \mathrm{H}, \mathrm{d}, J 4.2 \mathrm{~Hz}), 8.15(1 \mathrm{H}, \mathrm{d}, J 7.3 \mathrm{~Hz}), 8.07(1 \mathrm{H}, \mathrm{d}, J 7.8 \mathrm{~Hz}), 7.99(1 \mathrm{H}, \mathrm{d}, J 8.2 \mathrm{~Hz}), 7.87-7.82(1 \mathrm{H}, \mathrm{m})$, 7.81-7.86 (1H, m), 7.51 -7.47 (2H, m), 7.43-7.39 (2H, m), 4.87-4.79 (1H, m), 4.72-4.59 (3H, m), 4.55-4.51 (1H, m) ppm; ${ }^{13} \mathrm{C}-\mathrm{NMR}\left(100 \mathrm{MHz}, \mathrm{CDCl}_{3}\right) \delta 167.4,164.6,150.0,146.4,136.8,133.9,133.8,131.4,130.6,128.6$, $127.9,127.0,126.3,126.0,125.8,124.6,124.2,70.7,66.2,65.9$ ppm; IR 3371, 3056, 2953, 1710, 1509, 1238 $\mathrm{cm}^{-1}$; ESI-HRMS calcd. for $\mathrm{C}_{20} \mathrm{O}_{3} \mathrm{~N}_{2} \mathrm{H}_{16} 333.1293(\mathrm{M}+\mathrm{H})^{+}$found $\mathrm{m} / z$ 333.1196.

(4S)-2-(Pyridin-2-yl)-4,5-dihydrooxazol-4-ylmethyl adamantane-1-carboxylate (24). This was prepared according to the procedure reported above for benzoate 3 using oxazoline 1 (288 $\mathrm{mg}, 1.6 \mathrm{mmol})$ in $\mathrm{CH}_{2} \mathrm{Cl}_{2}(5$ $\mathrm{mL}), \mathrm{NEt}_{3}(0.45 \mathrm{~mL}, 3.2 \mathrm{mmol}$ ) and 1-adamantanecarbonyl chloride (483 mg, $2.4 \mathrm{mmol})$. After purification the reaction yielded the mono(oxazoline) ligand 24 as a viscous yellow oil (476 mg, 87\%). [ $\alpha]_{\mathrm{D}}+20.0$ (c $4.90 \times 10^{-3}$, $\left.\mathrm{CHCl}_{3}, 20{ }^{\circ} \mathrm{C}\right) ;{ }^{1} \mathrm{H}-\mathrm{NMR}\left(400 \mathrm{MHz}, \mathrm{CDCl}_{3}\right) \delta 8.70(1 \mathrm{H}, \mathrm{d}, J 4.8 \mathrm{~Hz}), 8.03(1 \mathrm{H}, \mathrm{d}, J 7.9 \mathrm{~Hz}), 7.78(1 \mathrm{H}, \mathrm{td}, J 7.8,1.9$ $\mathrm{Hz}), 7.40(1 \mathrm{H}, \mathrm{dd}, J 6.4,4.8 \mathrm{~Hz}), 4.64-4.53(2 \mathrm{H}, \mathrm{m}), 4.37-4.30(2 \mathrm{H}, \mathrm{m}), 4.22(1 \mathrm{H}, \mathrm{dd}, J 11.3,5.2), 1.93-1.58(15 \mathrm{H}$, m) ppm; ${ }^{13} \mathrm{C}-\mathrm{NMR}\left(100 \mathrm{MHz}, \mathrm{CDCl}_{3}\right) \delta 177.5,164.5,149.9,146.5,136.8,125.9,124.1,70.6,65.8,65.1,40.9$, 
38.8, 36.5, 27.9 ppm; IR 3391, 2904, 2851, 1724, 1641, $1071 \mathrm{~cm}^{-1}$; ESI-HRMS calcd. for $\mathrm{C}_{20} \mathrm{O}_{3} \mathrm{~N}_{2} \mathrm{H}_{24} 341.1865$ found $(\mathrm{M}+\mathrm{H})^{+} \mathrm{m} / \mathrm{z} 341.1831$.

(4S)-2-(Pyridin-2-yl)-4,5-dihydrooxazol-4-ylmethyl 4-chlorobenzoate (20). This was prepared according to the procedure reported above for benzoate 3 using oxazoline 1 (288 mg, $1.6 \mathrm{mmol}$ ) in $\mathrm{CH}_{2} \mathrm{Cl}_{2}(5 \mathrm{~mL}), \mathrm{NEt}_{3}(0.45$ $\mathrm{mL}, 3.2 \mathrm{mmol}$ ) and 4-chlorobenzoyl chloride $(0.3 \mathrm{~mL}, 2.4 \mathrm{mmol})$. After purification the reaction yielded the mono(oxazoline) 20 ligand as an pale yellow solid (362 mg, 76\%). [ $\alpha]_{\mathrm{D}}+17.1\left(\mathrm{c} 5.50 \times 10^{-3}, \mathrm{CHCl}_{3}, 20{ }^{\circ} \mathrm{C}\right.$ ); ${ }^{1} \mathrm{H}$ NMR $\left(400 \mathrm{MHz}, \mathrm{CDCl}_{3}\right) \delta 8.72(1 \mathrm{H}, \mathrm{d}, J 4.8 \mathrm{~Hz}), 8.05(1 \mathrm{H}, \mathrm{d}, J 7.9 \mathrm{~Hz}), 7.92(2 \mathrm{H}, \mathrm{d}, J 8.4 \mathrm{~Hz}), 7.79(1 \mathrm{H}, \mathrm{td}, J 7.8$, $1.7 \mathrm{~Hz}), 7.42(1 \mathrm{H}, \mathrm{dd}, J 6.5,4.8 \mathrm{~Hz}), 7.36(2 \mathrm{H}, \mathrm{d}, J 8.4 \mathrm{~Hz}), 4.79-4.72(1 \mathrm{H}, \mathrm{m}), 4.66(1 \mathrm{H}, \mathrm{dd}, J 9.8,8.7 \mathrm{~Hz}), 4.56$ $(1 \mathrm{H}, \mathrm{dd}, J \mathrm{11.3}, 4.3 \mathrm{~Hz}), 4.51-4.45(2 \mathrm{H}, \mathrm{m}) \mathrm{ppm} ;{ }^{13} \mathrm{C}-\mathrm{NMR}\left(400 \mathrm{MHz}, \mathrm{CDCl}_{3}\right) \delta 165.6,164.6,150.0,146.4,139.7$, $136.9,131.2,128.8,128.3,126.0,124.2,70.6,66.3,65.8$ ppm; IR 2968, 1716, 1639, 1591, $1276 \mathrm{~cm}^{-1}$; mp $92-$ $97^{\circ} \mathrm{C}$; ESI-HRMS calcd. for $\mathrm{C}_{16} \mathrm{O}_{3} \mathrm{~N}_{2} \mathrm{H}_{13} \mathrm{Cl} 317.0693(\mathrm{M}+\mathrm{H})^{+}$found $\mathrm{m} / z$ 317.0646.

(4S)-2-(Pyridin-2-yl)-4,5-dihydrooxazol-4-ylmethyl 4-nitrobenzoate (22). This was prepared according to the procedure reported above for benzoate 3 using oxazoline 1 (288 mg, $1.6 \mathrm{mmol})$ in $\mathrm{CH}_{2 \mathrm{~m} / \mathrm{z}} \mathrm{Cl}_{2}(5 \mathrm{~mL}), \mathrm{NEt}_{3}(0.45$ $\mathrm{mL}, 3.2 \mathrm{mmol}$ ) and 4-nitrobenzoyl chloride $(410 \mathrm{mg}, 2.4 \mathrm{mmol})$. After purification the reaction yielded the mono(oxazoline) ligand 22 as a yellow solid (394 mg, 75\%). ${ }^{1} \mathrm{H}-\mathrm{NMR}\left(400 \mathrm{MHz}, \mathrm{CDCl}_{3}\right) \delta 8.72(1 \mathrm{H}, \mathrm{d}, J 4.3 \mathrm{~Hz})$, $8.22(2 \mathrm{H}, \mathrm{d}, J 9.0 \mathrm{~Hz}), 8.15(2 \mathrm{H}, \mathrm{d}, J 8.9 \mathrm{~Hz}), 8.04(1 \mathrm{H}, \mathrm{d}, J 7.9 \mathrm{~Hz}), 7.80(1 \mathrm{H}, \mathrm{td}, J 7.8,1.8 \mathrm{~Hz}), 7.43(1 \mathrm{H}, \mathrm{dd}, J 6.6$, $4.9 \mathrm{~Hz}), 4.82-4.76(1 \mathrm{H}, \mathrm{m}), 4.69-4.65(1 \mathrm{H}, \mathrm{m}), 4.58(2 \mathrm{H}, \mathrm{d}, J 4.6 \mathrm{~Hz}), 4.47(1 \mathrm{H}, \mathrm{dd}, J$ 8.6, $7.3 \mathrm{~Hz}) \mathrm{ppm} ;{ }^{13} \mathrm{C}-\mathrm{NMR}$ $\left(100 \mathrm{MHz}_{1} \mathrm{CDCl}_{3}\right) \delta 164.7,164.5,150.6,149.9,146.1,136.8,135.0,130.8,126.0,124.1,123.5,70.3,66.8,65.5$ ppm; IR 2902, 1726, 1640, 1516, $1270 \mathrm{~cm}^{-1}$; MP 117-120 ㅇ; ESI-HRMS calcd. for $\mathrm{C}_{16} \mathrm{O}_{5} \mathrm{~N}_{3} \mathrm{H}_{13} 328.0933(\mathrm{M}+\mathrm{H})^{+}$ found $\mathrm{m} / \mathrm{z}$ 328.0901;

(4S)-2-(Pyridin-2-yl)-4,5-dihydrooxazol-4-ylmethyl 4-methylbenzoate (19). This was prepared according to the procedure reported above for benzoate 3 using oxazoline 1 (288 mg, $1.6 \mathrm{mmol}$ ) in $\mathrm{CH}_{2} \mathrm{Cl}_{2}(5 \mathrm{~mL}), \mathrm{NEt}_{3}$ $(0.45 \mathrm{~mL}, 3.2 \mathrm{mmol})$ and $p$-toluoyl chloride $(0.32 \mathrm{~mL}, 2.4 \mathrm{mmol})$. After purification the reaction yielded the mono(oxazoline) ligand 19 as a white solid (320 mg, 75\%). [ $\alpha]_{\mathrm{D}}+13.0$ (c $2.15 \times 10^{-3}, \mathrm{CHCl}_{3}, 20{ }^{\circ} \mathrm{C}$ ); ${ }^{1} \mathrm{H}-\mathrm{NMR}(400$ $\left.\mathrm{MHz}_{\mathrm{CDCl}}\right) \delta 8.72(1 \mathrm{H}, \mathrm{d}, J 4.8 \mathrm{~Hz}), 8.06(1 \mathrm{H}, \mathrm{d}, J 7.9 \mathrm{~Hz}), 7.88(2 \mathrm{H}, \mathrm{d}, J 8.2 \mathrm{~Hz}), 7.79(1 \mathrm{H}, \mathrm{td}, J 7.4,1.3 \mathrm{~Hz}), 7.41$ $(1 \mathrm{H}, \mathrm{dd}, J 6.6,4.8 \mathrm{~Hz}), 7.19(2 \mathrm{H}, \mathrm{d}, J 8.0 \mathrm{~Hz}), 4.80-4.73(1 \mathrm{H}, \mathrm{m}), 4.66-4.63(1 \mathrm{H}, \mathrm{m}), 4.57(2 \mathrm{H}, \mathrm{d}, J 4.4 \mathrm{~Hz}), 4.50-$ $4.44(1 \mathrm{H}, \mathrm{m}), 2.38(3 \mathrm{H}, \mathrm{s}) \mathrm{ppm} ;{ }^{13} \mathrm{C}-\mathrm{NMR}\left(100 \mathrm{MHz}, \mathrm{CDCl}_{3}\right) \delta 167.7,165.4,149.9,146.2,143.7,136.8,129.8$, $129.2,126.7,125.9,124.2,70.7,66.0,65.9,21.7$ ppm; IR 2957, 2901, 1713, 1653, 125 cm $^{-1}$; MP 93-96 우; ESIHRMS calcd. for $\mathrm{C}_{17} \mathrm{O}_{3} \mathrm{~N}_{2} \mathrm{H}_{16} 297.1239(\mathrm{M}+\mathrm{H})^{+}$found $\mathrm{m} / \mathrm{z} 297.1188$.

(4S)-2-(Pyridin-2-yl)-4,5-dihydrooxazol-4-ylmethyl 4-methoxybenzoate (23). This was prepared according to the procedure reported above for benzoate 3 using oxazoline 1 (288 mg, $1.6 \mathrm{mmol}$ ) in $\mathrm{CH}_{2} \mathrm{Cl}_{2}(5 \mathrm{~mL}), \mathrm{NEt}_{3}$ $(0.45 \mathrm{~mL}, 3.2 \mathrm{mmol}$ ) and 4-methoxybenzoyl chloride $(0.33 \mathrm{~mL}, 2.4 \mathrm{mmol})$. After purification the reaction yielded the mono(oxazoline) ligand 23 as a white solid (372 mg, 78\%). $[\alpha]_{\mathrm{D}}+10.4\left(c 5.20 \times 10^{-3}, \mathrm{CHCl}_{3}, 20{ }^{\circ} \mathrm{C}\right.$ ); ${ }^{1} \mathrm{H}-\mathrm{NMR}\left(400 \mathrm{MHz}, \mathrm{CDCl}_{3}\right) \delta 8.56(1 \mathrm{H}, \mathrm{d}, J 4.7 \mathrm{~Hz}), 8.19(2 \mathrm{H}, \mathrm{d}, J 7.8 \mathrm{~Hz}), 8.01(2 \mathrm{H}, \mathrm{d}, J 8.6 \mathrm{~Hz}), 7.85(1 \mathrm{H}, \mathrm{td}, J 7.7$, $1.7 \mathrm{~Hz}), 7.43(1 \mathrm{H}, \mathrm{dd}, J 6.6,4.9 \mathrm{~Hz}), 6.92(2 \mathrm{H}, \mathrm{d}, J 8.9 \mathrm{~Hz}), 4.61-4.45(5 \mathrm{H}, \mathrm{m}) 3.86(3 \mathrm{H}, \mathrm{s}, \mathrm{OCH}) \mathrm{ppm} ;{ }^{13} \mathrm{C}-\mathrm{NMR}$ $\left(100 \mathrm{MHz}, \mathrm{CDCl}_{3}\right) \delta 166.6,164.6,149.9,146.4,144.0,136.8,130.8,129.2,127.0,125.9,124.2,70.7,66.0,65.9$, 55.5 ppm; IR 2959, 2930, 1706, 1603, $863 \mathrm{~cm}^{-1}$; MP 102-105 우 ESI-HRMS calcd. for $\mathrm{C}_{17} \mathrm{O}_{4} \mathrm{~N}_{2} \mathrm{H}_{16} 313.1188$ $(\mathrm{M}+\mathrm{H})^{+}$found $\mathrm{m} / \mathrm{z} 313.1147$.

\section{Acknowledgements}

We acknowledge the College of Science NUI Galway for studentships provided to N. McC. and Z.C. 


\section{References}

1. Malacea, R.; Poli, R.; Manoury, E. Coord. Chem. Rev. 2010, 254, 729. https://doi.org/10.1016/i.ccr.2009.09.033

2. Ohkuma, T.; Ishii, D.; Takeno, H.; Noyori, R. J. Am. Chem. Soc. 2000, 122, 6510. https://doi.org/10.1021/ja001098k

3. Schnider, P.; Koch, G.; Prétôt, R.; Wang, G.; Bohnen, F. M.; Krüger, C.; Pfaltz, A. Chem. Eur. J. 1997, $3,887$. https://doi.org/10.1002/chem.19970030609

4. Echeverria, P.-G.; Férard, C.; Phansavath, P.; Ratovelomanana-Vidal, V. Catal. Commun. 2015, 62, 95. https://doi.org/10.1016/j.catcom.2015.01.012

5. Uematsu, N.; Fujii, A.; Hashiguchi, S.; Ikariya, T.; Noyori, R. J. Am. Chem. Soc. 1996, 118, 4916. https://doi.org/10.1021/ja960364k

6. Ou, Z.-M.; Shi, H.-B.; Sun, X.-Y.; Shen, W.-H. J. Mol. Catal. B: Enzym. 2011, 72, 294. https://doi.org/10.1016/j.molcatb.2011.07.004

7. Brunner, H.; Henrichs, C. Tetrahedron: Asymmetry 1995, 6, 653. https://doi.org/10.1016/0957-4166(95)90125-6

8. Nishibayashi, Y.; Takei, I.; Uemura, S.; Hidai, M. Organometallics 1998, 17, 3420. https://doi.org/10.1021/om980399o

9. Malkov, A. V.; Stewart-Liddon, A. J. P.; McGeoch, G. D.; Ramirez-Lopez, P.; Kocovsky, P. Org. Biomol. Chem. 2012, 10, 4864. https://doi.org/10.1039/c2ob25472g

10. Iwasaki, F.; Onomura, O.; Mishima, K.; Maki, T.; Matsumura, Y. Tetrahedron Lett. 1999, 40, 7507. https://doi.org/10.1016/S0040-4039(99)01554-3

11. Iwasaki, F.; Onomura, O.; Mishima, K.; Kanematsu, T.; Maki, T.; Matsumura, Y. Tetrahedron Lett. 2001, 42, 2525.

https://doi.org/10.1016/S0040-4039(01)00219-2

12. Malkov, A. V.; Mariani, A.; MacDougall, K. N.; Kočovský, P. Org. Lett. 2004, 6, 2253. https://doi.org/10.1021/ol049213+

13. Malkov, A. V.; Figlus, M.; Stončius, S.; Kočovský, P. J. Org. Chem. 2007, 72, 1315. https://doi.org/10.1021/j0062215i

14. Zhou, L.; Wang, Z.; Wei, S.; Sun, J. Chem. Commun. 2007, 2977. https://doi.org/10.1039/b703307a

15. Zheng, H.; Deng, J.; Lin, W.; Zhang, X. Tetrahedron Lett. 2007, 48, 7934. https://doi.org/10.1016/i.tetlet.2007.09.064

16. Guizzetti, S.; Benaglia, M.; Cozzi, F.; Annunziata, R. Tetrahedron 2009, 65, 6354. https://doi.org/10.1016/j.tet.2009.06.015

17. Gautier, F.-M.; Jones, S.; Li, X.; Martin, S. J. Org. Biomol. Chem. 2011, 9, 7860. https://doi.org/10.1039/c1ob05965c

18. Pei, D.; Wang, Z.; Wei, S.; Zhang, Y.; Sun, J. Org. Lett. 2006, 8, 5913. https://doi.org/10.1021/ol062633+

19. Malkov, A. V.; Liddon, A.; Ramirez-Lopez, P.; Bendova, L.; Haigh, D.; Kocovsky, P. Angew. Chem. Int. Ed. 2006, 45, 1432. https://doi.org/10.1002/anie.200503941

20. Frain, D.; Kirby, F.; McArdle, P.; O'Leary, P. Synlett 2009, 1261. 
https://doi.org/10.1055/s-0029-1216731

21. Frain, D.; Kirby, F.; McArdle, P.; O'Leary, P. Tetrahedron Lett. 2010, 51, 4103.

https://doi.org/10.1016/j.tetlet.2010.05.135

22. Kirby, F.; Frain, D.; McArdle, P.; O'Leary, P. Catal. Commun. 2010, 11, 1012.

https://doi.org/10.1016/j.catcom.2010.05.003

23. Balavoine, G.; Clinet, J. C.; Lellouche, I. Tetrahedron Lett. 1989, 30, 5141.

https://doi.org/10.1016/S0040-4039(01)93469-0

24. 24 Çelebi-Ölçüm, N.; Lam, Y.-h.; Richmond, E.; Ling, K. B.; Smith, A. D.; Houk, K. N. Angew. Chem. Int. Ed. 2011, 50, 11478.

https://doi.org/10.1002/anie.201105412

25. Kenworthy, M. N.; Kilburn, J. P.; Taylor, R. J. K. Org. Lett. 2004, 6, 19.

https://doi.org/10.1021/ol0360039

26. Castellano, S.; Kuck, D.; Sala, M.; Novellino, E.; Lyko, F.; Sbardella, G. J. Med. Chem. 2008, $51,2321$. https://doi.org/10.1021/im7015705

27. Schulz, M.; Christoffers, J. Synthesis 2014, 46, 81.

https://doi.org/10.1055/s-0033-1340044

28. Motloch, P.; Valterová, I.; Kotora, M. Adv. Synth. Catal. 2014, 356, 199.

https://doi.org/10.1002/adsc.201300849

29. 29 Kim, Y.-A.; Chung, H.-M.; Park, J.-S.; Choi, W.; Min, J.; Park, N.-H.; Kim, K.-H.; Jhon, G.-J.; Han, S.-Y. J. Org. Chem. 2003, 68, 10162.

https://doi.org/10.1021/j0034969s 